\title{
A predictive modeling approach to test distributional uniformity of Uruguayan harvestmen (Arachnida: Opiliones)
}

\author{
Miguel Simó ${ }^{1,2,3^{*}+}$, José Carlos Guerrero ${ }^{3,4}$, Leandro Giuliani ${ }^{1}$, Ismael Castellano ${ }^{1}$ and Luis E Acosta ${ }^{5,6+}$
}

\begin{abstract}
Background: Harvestmen are a good taxon for biogeographic studies due to their low vagility and their dependence on environmental conditions which make most of them live in humid and shaded habitats. Current knowledge of the geographical distribution of Uruguayan opiliofauna suggests that no evident zoogeographic areas are present, mainly because of the apparent uniformity of the landscape of this country. Recent biogeographic studies indicate that Uruguay represents a biogeographical crossroad between three South American provinces, and the aim of this study is focused on determining if this fact is reflected in the distribution of the Uruguayan opiliofauna. To test this presumption, we used the species distribution model methodology. Distribution data about four harvestmen species from Uruguay and neighboring countries were analyzed. We used the maximum entropy principle to perform a distribution model for each species.

Results: We recognized Acanthopachylus aculeatus and Pachyloides thorellii as two Pampasic representatives of the Uruguayan opiliofauna. The other species studied, Discocyrtus prospicuus and Metalibitia paraguayensis, reflect Mesopotamian and Paranaense influences in the Uruguayan territory. Isothermality was the climatic variable with the best contribution in the models of the four species, reflecting constrained latitudinal ranges.

Conclusions: Results of the present study suggest that two roughly different opiliological areas for Uruguay can be recognized, based on climatic variables.
\end{abstract}

Keywords: Opiliofauna; Potential distribution; Biogeographic patterns; South America; Neotropical

\section{Background}

Present knowledge on the diversity of Uruguayan harvestmen is mainly based on the contributions made by Ringuelet (1955, 1963) and Capocasale (1968, 1993, 2003). The latter paper (Capocasale 2003) consists of a catalogue, in which a total of 25 species belonging to 5 families were cited for the country. In his contributions, Capocasale $(1968,2003)$ also provided a coarse reference to the species distributions, either indicating the occurrence localities on a map (Capocasale 1968) or merely assigning them to the administrative divisions (departments) (Capocasale 2003). Indeed, this author explicitly avoided

\footnotetext{
* Correspondence: simo@fcien.edu.uy

${ }^{\dagger}$ Equal contributors

'Sección Entomología, Facultad de Ciencias, Universidad de la República, Iguá 4225, Montevideo 11400, Uruguay

${ }^{2}$ Laboratorio de Entomología, Museo Nacional de Historia Natural Nacional,

25 de Mayo 582, Montevideo 11000, Uruguay

Full list of author information is available at the end of the article
}

recognizing zoogeographic areas since he considered that harvestmen species were distributed quite uniformly throughout the country (i.e., distributional patterns were not apparent for him). Following a similar rationale, Kury (2003) stressed that the opiliofauna of Uruguay was the poorest in South America, allegedly due to the environmental uniformity of the landscape of this country as assessed by most 'classical' biogeographic approaches, like Cabrera and Willink (1973) and Morrone (2002). Besides this, such a low species richness of the Uruguayan opiliofauna associated to the small size of the territory might seem an obvious correlation.

As a fact, the Uruguayan territory is extensively dominated by grasslands, which results in a recognizable landscape uniformity (Evia and Gudynas 2000). In their revised map of the ecoregions of the world, Olson et al. (2001) place Uruguay, together with the southern portion of the Brazilian state Rio Grande do Sul, in an ecoregion thereby 
named 'Uruguayan savanna'. Morrone (2002) locates Uruguay in the 'Pampa province', which also comprises eastern Argentina (provinces of Buenos Aires and Entre Ríos) and southern Brazil, as mentioned above. The Pampas are characterized by savannas covered by 1 -m-high temperate grasslands and shrubs. This homogeneous picture, however, might be a 'thick-brush' oversimplification that hides some patterns. At least for harvestmen, distributions in Uruguay still remain poorly surveyed in large parts of the country, so the alleged uniformity might reflect lack of knowledge. More importantly, Uruguayan environments were actually shown to be more diverse than it seems in a quick glance. Grela (2004) demonstrated that the Uruguayan dendroflora is represented by two quite distinct areas: the Oriental one, mainly influenced by the Paranaense Forest, together with a small intromission of Cerrado, and the Occidental area, where two provinces converge: Chaco and Paranaense Forest, sensu Morrone (2002). The biogeographical affinities between the Pampean Province in Argentina and Uruguay were already indicated for varied taxonomic groups, like Asteraceae (Crisci et al. 2001), Pleistocene mammals (Carlini et al. 2004), as well as harvestmen (Acosta 2002) and scorpions (Acosta 1993; Mattoni and Acosta 1997; Acosta et al. 2008). Furthermore, this area is a part of the 'peripampasic arc', a biogeographical track that comprises ancient mountain systems with biotic connections, where a high biodiversity and endemic species converge (Acosta 1993; Acosta and Maury 1998a, b; Acosta et al. 2008; Ferretti et al. 2012). Ferretti et al. (2012) recognized a mygalomorph spider track connecting part of Argentina, Uruguay, and southern Brazil. Recently, Laborda et al. (2012) reported the southernmost record in lower Uruguay River of a spider species associated to subtropical forests from Northeastern Argentina. This record represents new evidence that supports the proposal that this river acts as a biological corridor that allows the intromission of the Paranaense Forest and Chaco Provinces in Uruguay, as proposed by Grela (2004).

The scarcity of records, together with their evident geographical bias around the capital city, Montevideo (see, e.g., Capocasale 1968), might be considered a concrete hindrance to get a valid overview of range patterns. To overcome this problem, we used the benefits of building models of potential distribution, using an ecological niche modeling approach, based on bioclimatic suitability for selected species. Range modeling is considered a good way to predict a species distribution when presence points are deemed to be incomplete, and at the same time, it provides accurate results and biologically meaningful fit between species occurrence and environment variables (Van Der Wal et al. 2009; Peterson et al. 2011). In this sense, we take advantage of one property that makes harvestmen a good taxon for biogeographic studies: their apparent dependence on environmental conditions, like temperature and humidity (Acosta 2002, 2008; Acosta and Guerrero 2011; Pinto da Rocha et al. 2005, 2007).

The present study was focused to test whether the alleged uniformity of the Uruguayan landscape applies for the opiliofauna, or, instead, the country congregates different opiliological components as a result of a biogeographic crossroad. Our aim is to verify if modeled ranges of selected species are able to properly depict different biogeographical affinities for harvestmen. In any case, distribution models will represent a first step to study the regional biogeographic influence on the distribution of Uruguayan harvestmen species.

\section{Methods}

\section{Species and occurrence data}

For this study, we selected four species of Uruguayan harvestmen: the gonyleptids Acanthopachylus aculeatus (Kirby 1818), Discocyrtus prospicuus (Holmberg 1876), and Pachyloides thorellii Holmberg 1878, and the cosmetid Metalibitia paraguayensis (Sørensen 1884). These species were selected because of the availability of enough point records (not less than 60), not only from Uruguay but also from their whole range, i.e., also comprising Argentina, Brazil, and Paraguay. A part of the records originated in the literature (Sørensen 1884; Soares and Soares 1986; Ringuelet 1959, 1963; Capocasale 1968; Capocasale and Gudynas 1993; Acosta 1989, 1992, 1999, 2002; Kury 2003; Toscano-Gadea and Simó 2004; Guerrero 2011; Acosta and Guerrero 2011); in those cases, the easy identification of the mentioned species assured our confidence in their taxonomical accuracy. Many additional records were obtained from Uruguayan arachnological collections: Museo Nacional de Historia Natural, Montevideo (MNHN) and Sección Entomología, Facultad de Ciencias, Universidad de la República (FCEOp). Localities were georeferenced using Gazzetter Diva GIS (http://www.diva-gis.org/gData), Google Earth (http:// earth.google.es/), and Map Planet (http://www.mapplanet. $\mathrm{com} /$ ). Imprecise or doubtful records were not considered in this study. The database used for modeling consisted of 129 unique locality records for $A$. aculeatus, 68 for $P$. thorellii, and 65 for $M$. paraguayensis. Dataset of $D$. prospicuus comprises all 80 point records reported by Acosta and Guerrero (2011). The complete record set for Uruguay, including the new records for all four species, is detailed in Table 1.

\section{Environmental variables}

Bioclimatic variables were obtained from the WorldClim database (http://www.worldclim.org/), at a resolution of 30 arc sec, i.e., about $1 \times 1 \mathrm{~km}$ (Hijmans et al. 2005a, b). It comprises 19 bioclimatic variables derived from maximum, minimum, and averages of temperature and 
Table 1 Complete record set for Uruguay of Discocyrtus prospicuus, Pachyloides thorellii, Acanthopachylus aculeatus, and Metalibitia paraguayensis, with geographical coordinates

\begin{tabular}{|c|c|c|c|c|}
\hline Department & Locality & Longitude (W) & Latitude (S) & Source \\
\hline \multicolumn{5}{|c|}{ Discocyrtus prospicuus } \\
\hline Artigas & Isla Rica & -57.8840 & -30.5311 & Capocasale (1968) \\
\hline Artigas & Isla Zapallo & -57.8737 & -30.4989 & Acosta and Guerrero (2011) \\
\hline Canelones & Villa Argentina & -55.7793 & -34.7708 & Acosta and Guerrero (2011) \\
\hline Colonia & Barra de Rosario & -57.3506 & -34.4368 & NR: $10 \hat{,}, 2$ o (FCE-Op 318), 12-vi-1960 (L. C. de Zolessi) \\
\hline Colonia & Barrancas de San Pedro & -57.9077 & -34.3614 & Acosta and Guerrero (2011) \\
\hline Colonia & Colonia & -57.8656 & -34.4371 & Acosta and Guerrero (2011) \\
\hline Colonia & Nueva Palmira & -58.4136 & -33.8662 & Acosta and Guerrero (2011) \\
\hline Colonia & Punta Arroyo Limetas & -58.1053 & -34.1728 & Capocasale (1968) \\
\hline Colonia & Punta Gorda & -58.4175 & -33.9117 & Capocasale (1968) \\
\hline Lavalleja & Parque Sierra Minas & -55.1973 & -34.4260 & Acosta and Guerrero (2011) \\
\hline Paysandú & Paysandú & -58.0889 & -32.3005 & Acosta and Guerrero (2011) \\
\hline Río Negro & Fray Bentos & -58.2500 & -33.1133 & Acosta and Guerrero (2011) \\
\hline Salto & Isla Redonda & -57.9154 & -31.1673 & Acosta and Guerrero (2011) \\
\hline San José & Arazatí & -56.9992 & -34.5577 & Capocasale (1968) \\
\hline \multicolumn{5}{|c|}{ Pachyloides thorellii } \\
\hline Canelones & Canelones & -56.2833 & -34.5333 & 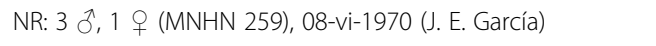 \\
\hline \multirow[t]{2}{*}{ Canelones } & Marindia & -55.8261 & -34.7805 & Toscano-Gadea and Simó (2004) \\
\hline & & & & $\begin{array}{l}\text { NR: } 1 \text { q (FCE-Op 158), } 1 \text { immature (FCE-Op 159), 1-vii-2004 } \\
\text { (C. Toscano-Gadea); } 4 \text { ơ (FCE-Op 181), 1-vii-2002 } \\
\text { (C. Toscano-Gadea) }\end{array}$ \\
\hline Canelones & San José de Carrasco & -55.9820 & -34.8518 & NR: $2 \hat{\jmath}$ (FC-Op 190), 9-viii-2002 (C. Toscano-Gadea) \\
\hline Canelones & Santa Lucía del Este & -56.4859 & -34.7440 & Capocasale (1968) \\
\hline Canelones & Villa Argentina & -55.7773 & -34.7703 & Capocasale (1968) \\
\hline Cerro Largo & Río Tacuarí & -54.0100 & -32.6262 & NR: 1 q (MNHN 1129), 13-iv-1965 (F. Achaval) \\
\hline Colonia & Arroyo Cufré & -57.3333 & -34.4333 & Capocasale (1968) \\
\hline Colonia & Colonia Suiza & -57.2166 & -34.3166 & NR: $1 \widehat{\jmath}$ (MNHN 217), 10-i-1971 (E. Corbella and R. Gutiérrez) \\
\hline Florida & Florida & -56.2159 & -34.1095 & Kury (2003) \\
\hline Lavalleja & Arequita & -55.2833 & -34.2500 & Capocasale (1968) \\
\hline Lavalleja & Gruta Arequita & -55.2673 & -34.2889 & Kury (2003) \\
\hline Lavalleja & Cerro de los Cuervos & -55.2585 & -34.2846 & $\begin{array}{l}\text { NR: } 1 \text { đ (FCE-Op 108), 23-ix-1997 (M. Simó and G. Useta); } \\
1 \text { đે (FCE-Op 114), 17-x-1998 (M. Simó and G. Useta); } \\
1 \text { immature (FCE-Op 126), 15-viii-1998 (M. Simó) }\end{array}$ \\
\hline Lavalleja & Cerro de las Chivas & -54.6791 & -33.8898 & NR: 1 q (FCE-Op 79), 06-ix-1959 \\
\hline Maldonado & Abra de Perdomo & -54.9666 & -34.7333 & NR: 2ð (MNHN 260), 17-v-1970 (A. Romero and J. E. García) \\
\hline Maldonado & Barra Arroyo Maldonado & -54.8666 & -34.8666 & $\begin{array}{l}\text { NR: } 2 \text { ð (MNHN 1106), } 1 \text { ð (MNHN 1151), 22-xi-1963 } \\
\text { (M. Klappenbach) }\end{array}$ \\
\hline Maldonado & Sierra de las Ánimas & -55.3166 & -34.7666 & Capocasale (1968); Capocasale and Gudynas (1993) \\
\hline Maldonado & Grutas de Salamanca & -54.5666 & -34.0333 & Capocasale (1968) \\
\hline Maldonado & Isla de Lobos & -54.8845 & -35.0267 & Capocasale (1968) \\
\hline Maldonado & Laguna de Maldonado & -55.0300 & -34.8472 & NR: $1 ð$ (FCE-Op 94), 27-i-2001 \\
\hline Maldonado & Pan de Azúcar & -55.3936 & -34.7426 & Capocasale (1968) \\
\hline Maldonado & Punta Ballena & -55.0285 & -34.8976 & Capocasale (1968) \\
\hline Maldonado & Punta del Este & -54.9146 & -34.9428 & NR: 19 (MNHN 255), 23-vi-1970 (J. E. García) \\
\hline Montevideo & Buceo & -56.1333 & -34.9000 & Capocasale (1968) \\
\hline Montevideo & Camino Las Tropas & -56.2543 & -34.8435 & Capocasale (1968) \\
\hline
\end{tabular}


Table 1 Complete record set for Uruguay of Discocyrtus prospicuus, Pachyloides thorellii, Acanthopachylus aculeatus, and Metalibitia paraguayensis, with geographical coordinates (Continued)

\begin{tabular}{|c|c|c|c|c|}
\hline Montevideo & Campo de Golf & -56.1635 & -34.9250 & Capocasale (1968) \\
\hline Montevideo & Malvín & -56.1152 & -34.8973 & Capocasale (1968) \\
\hline Montevideo & Malvín Norte & -56.1130 & -34.8741 & NR: $1 \jmath^{\lambda}$ (FC-Op 119), 22-xi-2004 (H. Coitiño) \\
\hline Montevideo & Melilla & -56.2500 & -34.7833 & NR: $1 \hat{\jmath}$ (FCE-Op 6), 08-iii-1998 (F. Costa) \\
\hline Montevideo & Parque Rodó & -56.1668 & -34.9132 & Kury (2003) \\
\hline Montevideo & Parque Zorrilla & -56.1536 & -34.9207 & Capocasale (1968) \\
\hline Montevideo & Prado & -56.1966 & -34.8663 & NR: 1 đૈ (MNHN 215), 13-i-1971 (E. Goberna) \\
\hline Montevideo & Puerto Buceo & -56.1326 & -34.9105 & Capocasale (1968) \\
\hline Montevideo & Punta Carretas & -34.9000 & -56.0666 & Capocasale (1968) \\
\hline Montevideo & Sayago & -56.2333 & -34.8333 & Capocasale (1968) \\
\hline Paysandú & Paysandú & -58.0755 & -32.3213 & NR: 5 immatures (FCE-Op 139), 09-viii-2005 \\
\hline Rocha & Palmares de San Luis & -53.7166 & -33.6166 & NR: 1 q (MNHN 315), 13-i-1957 (C. Carbonell) \\
\hline Rocha & La Coronilla & -53.8500 & -33.5666 & NR: $10^{\pi}$ (MNHN 225), 26-ii-1970 (L. A. de Gambardella) \\
\hline Rocha & Potrero Grande & -53.7287 & -33.8999 & 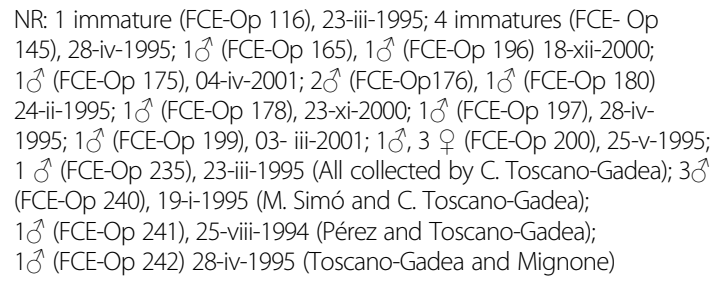 \\
\hline Rocha & Bocas del Sarandí & -54.1928 & -34.1959 & 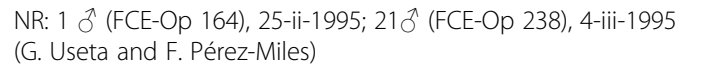 \\
\hline Rocha & Sarandí del Consejo & -53.9990 & -34.3015 & NR: 1 ð (FCE-Op 201), 29-iv-1995 \\
\hline San José & Sierra Mahoma & -56.9333 & -34.0833 & NR: 20̄, 1 ㅇ (MNHN 1262), 29-viii-1965 (F. Achaval) \\
\hline Treinta y Tres & Río Olimar & -54.8000 & -32.9166 & NR: 1 immature (MNHN 1091), 22-ix-1963 \\
\hline Treinta y Tres & Cerro Chato & -55.1166 & -33.0833 & NR: $10 \widehat{~(M N H N ~ 1234), ~ 26-i i i-1964 ~(R . ~ C a p o c a s a l e ~ a n d ~ B r u n o) ~}$ \\
\hline \multicolumn{5}{|c|}{ Acanthopachylus aculeatus } \\
\hline Canelones & Canelón Grande & -56.4000 & -34.5000 & Capocasale (1968) \\
\hline Canelones & Estación la Pedrera & -55.8166 & -34.6166 & NR: 1 ㅇ (FCE-Op 239), 16-x-2002 (F. Costa) \\
\hline Canelones & Marindia & -56.1000 & -34.8166 & $\begin{array}{l}\text { Toscano-Gadea and Simó (2004). NR: 7ð } 209 \text { (FCE-Op 92), } \\
\text { 16-i-1977 (G. Olivera); } 1 \text {, } 1 \text { immature (FCE-Op 193), 1-vii-2002 } \\
\text { (C. Toscano-Gadea) }\end{array}$ \\
\hline Canelones & Los Titanes & -55.5452 & -34.7861 & Capocasale (1968) \\
\hline Canelones & Piedras de Afilar & -55.5333 & -34.7166 & NR: $1 \hat{\partial}$ (FCE-Op 174), 05-vii-2004 (A. Aisenberg and G. Useta) \\
\hline Canelones & San José de Carrasco & -55.9820 & -34.8518 & $\begin{array}{l}1 \hat{\jmath}, 7 \text { ㅇ (FCE-Op 172), 08-ix-2002 (C. Toscano-Gadea); } \\
1 \text { immature (FCE-Op 194), 09-viii-2002 (C. Toscano-Gadea) }\end{array}$ \\
\hline Canelones & Santa Lucía del Este & -56.4859 & -34.7440 & Capocasale (1968) \\
\hline Canelones & Villa Argentina & -55.7773 & -34.7703 & Capocasale (1968). NR: 1 ㅇ (FCE-Op 90), viii-2002 (F. Costa) \\
\hline Cerro Largo & Camino Las Cuentas & -54.5971 & -32.6197 & Capocasale (1968) \\
\hline Cerro Largo & Cerro de las Cuentas & -54.6000 & -32.6166 & Capocasale (1968) \\
\hline Cerro Largo & Sarandí del Quebracho & -54.6333 & -32.6833 & Capocasale (1968) \\
\hline Cerro Largo & Sierras de Aceguá & -54.4166 & -31.9000 & Capocasale (1968) \\
\hline Cerro Largo & Ruta 8. Río Tacuarí & -54.0100 & -32.6262 & NR: 1 đ̆ (MNHN Z042/1217) 15-iv-1965 (F. Achaval) \\
\hline Colonia & Barra del Rosario & -57.3500 & -34.4333 & Capocasale (1968) \\
\hline Colonia & Carmelo & -58.2958 & -33.9936 & Ringuelet (1963) \\
\hline Colonia & Punta Gorda & -58.4000 & -33.9333 & Capocasale (1968) \\
\hline Durazno & Arroyo Las Cañas & -55.6833 & -32.7666 & NR: 1q, 4 immatures (MNHN 262) 15-viii-1970 (J. E. García) \\
\hline
\end{tabular}


Table 1 Complete record set for Uruguay of Discocyrtus prospicuus, Pachyloides thorellii, Acanthopachylus aculeatus, and Metalibitia paraguayensis, with geographical coordinates (Continued)

\begin{tabular}{|c|c|c|c|c|}
\hline Durazno & Cerro Chato & -55.1166 & -33.0833 & Capocasale (1968) \\
\hline Lavalleja & Aguas Blancas & -55.4492 & -34.5172 & Capocasale (1968) \\
\hline Lavalleja & Cerro Arequita & -55.2833 & -34.2500 & 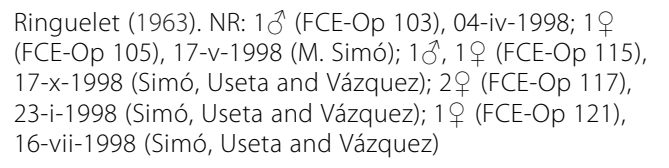 \\
\hline Lavalleja & Cerro de los Cuervos & -55.2585 & -34.2846 & $\begin{array}{l}\text { NR: 10, } 29 \text { (FCE-Op 107), 23-ix-1997 (M. Simó and G. Useta); } \\
\text { 19 (FCE-Op120), 22-iii-2004 (C. Toscano-Gadea) }\end{array}$ \\
\hline Lavalleja & Cerro de las Chivas & -54.6791 & -33.8898 & NR: 5 ふૈ, 5 o, 12 immatures (FCE-Op 273), 06-ix-1959 \\
\hline Lavalleja & Solís de Mataojo & -55.0666 & -34.1000 & Capocasale (1968) \\
\hline Lavalleja & Cerro del Penitente & -55.1666 & -34.3500 & Capocasale (1968) \\
\hline Lavalleja & Sierra de Minas & -55.3333 & -34.5000 & Capocasale (1968) \\
\hline Maldonado & Abra de Perdomo & -54.9666 & -34.7333 & $\begin{array}{l}\text { NR: } 4 \text { 9 (MNHN 261), 17-v-1970 (A. Romero and J. E. García); } \\
10 \text { 10, } 1 \text { o (MNHN 263), 7-vi-1960 (A. Romero and C. Barlocco) }\end{array}$ \\
\hline Maldonado & Arroyo Maldonado & -54.8666 & -34.8666 & NR: 7ð̂, 27ㅇ (MNHN P54), 22-xi-1963 (M. Klappenbach) \\
\hline Maldonado & Balneario Solís & -55.3666 & -34.8000 & NR: $10^{\pi}$ (MNHN P30), 27-x-1963 (R. Praderi) \\
\hline Maldonado & Cerro Catedral & -54.6833 & -34.3333 & NR: 10, 10ㅇ (FCE-Op 229), 07-v-2002. (F. Costa) \\
\hline Maldonado & Cerro de las Ánimas & -55.3166 & -34.7666 & Ringuelet (1963), Capocasale (1968) \\
\hline Maldonado & Sierra de las Ánimas & $-55,3166$ & $-34,7000$ & NR: 1 (FCE-Op 106), 03-iv-1987 (A. Brady) \\
\hline Maldonado & Cerro del Toro & -55.2666 & -34.8666 & NR: $1 \widehat{\jmath}$ (MNHN P59), 29-xi-1953 \\
\hline Maldonado & Cerro Pan de Azúcar & -55.2666 & -34.8333 & Capocasale (1968) \\
\hline Maldonado & Punta Ballena & -55.0285 & -34.8976 & Capocasale (1968) \\
\hline Maldonado & Punta del Este & -54.9146 & -34.9428 & NR: 1 ㅇ (MNHN 254), 23-vi-1970 (J. E. García) \\
\hline Maldonado & San Carlos & -54.9166 & -34.8000 & Capocasale (1968) \\
\hline Montevideo & Buceo & -56.1333 & -34.9000 & Capocasale (1968) \\
\hline Montevideo & Buceo, Puerto & -56.1326 & -34.9105 & Capocasale (1968) \\
\hline Montevideo & Campo de Golf & -56.1635 & -34.9250 & Capocasale (1968) \\
\hline Montevideo & Cañada de las Yeguas & -56.3066 & -34.8942 & NR: 1 ㅇ (FCE-Op 112), 30-ix-1995 \\
\hline Montevideo & Cerro (1) & -56.2666 & -34.8500 & Capocasale (1968) \\
\hline Montevideo & Cerro (2) & $-56,2114$ & $-34,8298$ & NR: 2o (FCE-Op 202), v-1980 \\
\hline Montevideo & Colón & -56.2333 & -34.8000 & Capocasale (1968) \\
\hline Montevideo & Manga & -56.1000 & -34.8166 & Capocasale (1968) \\
\hline Montevideo & Melilla & -56.2500 & -34.7833 & 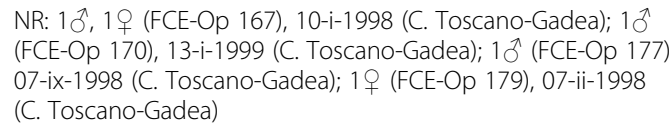 \\
\hline Montevideo & Parque Lecocq & -56.3306 & -34.7892 & Capocasale (1968) \\
\hline Montevideo & Parque Rodó & -56.1701 & -34.9097 & Capocasale (1968) \\
\hline Montevideo & Parque Rodó, Canteras & -56.1700 & -34.9090 & Capocasale (1968) \\
\hline Montevideo & Parque Zorrilla & -56.1536 & -34.9207 & Capocasale (1968) \\
\hline Montevideo & Paso de la Arena & -56.2666 & -34.8333 & Capocasale (1968) \\
\hline Montevideo & Punta Carretas & -56.0666 & -34.9000 & Capocasale (1968) \\
\hline Montevideo & Punta Espinillo & -56.4161 & -34.8308 & Capocasale (1968) \\
\hline Montevideo & Punta Gorda & -56.0815 & -34.8992 & NR: 7 immatures (FCE-Op 100), 10-vii-2003 \\
\hline Montevideo & Rambla Naciones Unidas & -56.1375 & -34.9103 & Capocasale (1968) \\
\hline Montevideo & Sayago & -56.2333 & -34.8333 & Capocasale (1968) \\
\hline Paysandú & Pueblo Constancia & -58.0000 & -32.2000 & NR: $1 \lesssim, 2$ (FCE-Op 101), 04-i-2004 \\
\hline
\end{tabular}


Table 1 Complete record set for Uruguay of Discocyrtus prospicuus, Pachyloides thorellii, Acanthopachylus aculeatus, and Metalibitia paraguayensis, with geographical coordinates (Continued)

\begin{tabular}{|c|c|c|c|c|}
\hline Paysandú & Ruta 3. km 420 & -57.8465 & -32.0359 & Capocasale (1968) \\
\hline Río Negro & Arroyo Salsipuedes & -56.6166 & -32.5500 & $\begin{array}{l}\text { NR: 50र, } 99,39 \text { immatures (MNHN 200), } 1 \text { ( }(\text { MNHN 265), } \\
\text { 22- viii-1970 (E. García) }\end{array}$ \\
\hline Rivera & Arroyo Lunarejo & -55.8333 & -31.2500 & NR: 30̂, 3ㅇ (FCE-Op 137), 1995 \\
\hline Rocha & Bocas del Sarandí & -54.1928 & -34.1959 & NR: 19 (FCE-Op 185), 25-ii-1995 (C. Toscano-Gadea) \\
\hline Rocha & Cabo Polonio & -53.7833 & -34.4000 & $\begin{array}{l}\text { Capocasale (1968). NR: } 1 \delta \text {, } 1 \text { ㅇ (FCE-Op 186), 18-iii-2004 } \\
\text { (F. Achaval) }\end{array}$ \\
\hline Rocha & Colonia Don Bosco & -53.7481 & -34.0743 & NR: $1 \lesssim$ (FCE-Op 110), 29-vi-2001 \\
\hline Rocha & La Coronilla & -53.8500 & -33.5666 & NR: 1 q (MNHN 208), 26-ii-1970 (L. A. de Gambardella) \\
\hline Rocha & Santa Teresa & -53.5333 & -33.9833 & NR: 19 (MNHN 207), 09-ii-1970 (H. Bonino) \\
\hline Rocha & San Luis & -53.7166 & -33.6166 & Capocasale (1968) \\
\hline San José & Playa Pascual & -56.5833 & -34.7500 & Capocasale (1968) \\
\hline San José & Sierra de Mahoma & -56.9333 & -34.0833 & Capocasale (1968) \\
\hline Tacuarembó & Paso Borracho & -55.4666 & -31.9000 & Capocasale (1968) \\
\hline Tacuarembó & Puntas Arroyo Laureles & -56.1500 & -32.6000 & Capocasale (1968) \\
\hline Treinta y Tres & Quebrada de los Cuervos & -54.4500 & -33.1666 & Ringuelet (1963) \\
\hline Treinta y Tres & Santa Clara de Olimar & -54.9666 & -32.9166 & Capocasale (1968) \\
\hline \multicolumn{5}{|c|}{ Metalibitia paraguayensis } \\
\hline Artigas & Arroyo Cuaró & -56.5000 & -30.6833 & Capocasale (1968) \\
\hline Artigas & Arroyo de la Invernada & -56.0166 & -30.8000 & Capocasale (1968) \\
\hline Artigas & Pedregal & -57.7133 & -30.7138 & $\begin{array}{l}\text { NR: } 1 \text { Ô, } 2 \text { o (FCE-Op 98), 10-x-1978 (Zolessi, Morelli } \\
\text { and Rodríguez) }\end{array}$ \\
\hline Artigas & Ruta 30 & -56.8040 & -30.4398 & Capocasale (1968) \\
\hline Cerro Largo & Sarandí del Quebracho & -54.6333 & -32.6833 & NR: 1 ô (FCE-Op 75), 18-vi-1954 \\
\hline Cerro Largo & Sierra de Aceguá & -54.4166 & -31.9000 & 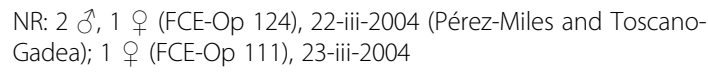 \\
\hline Maldonado & Cerro de las Ánimas & -55.3166 & -34.7666 & Capocasale (1968) \\
\hline Maldonado & Grutas de Salamanca & -54.5666 & -34.0333 & Capocasale (1968) \\
\hline Montevideo & Cañada de las Yeguas & -56.3066 & -34.8942 & NR: 1 q (FCE-Op 113), 30-ix-1995 \\
\hline Rivera & Arroyo Carpintería & -54.4833 & -31.8000 & Capocasale (1968) \\
\hline Rivera & Arroyo Lunarejo & -55.8333 & -31.2500 & Capocasale (1968) \\
\hline Rivera & Ruta 5. Cerro Chivos & -55.8261 & -31.3718 & NR: 2 đ, 1 ㅇ (MNHN 1450), 03-vi-1962 (P. San Martín) \\
\hline Rivera & Subida de Pena (1) & -55.9278 & -31.1086 & Capocasale (1968) \\
\hline Rivera & Subida de Pena (2) & -56.8040 & -30.4398 & Capocasale (1968) \\
\hline Rivera & Sierra de la Aurora & -55.7166 & -31.0500 & Capocasale (1968) \\
\hline Salto & Arapey & -33.0833 & -55.1166 & NR: 6 đ̂ं (FCE - Op 59), 13-iii-1972 (L. A. González) \\
\hline Salto & Salto Grande & -57.9166 & -31.2333 & Capocasale (1968) \\
\hline San José & Sierra de Mahoma & -56.9333 & -34.0833 & Capocasale (1968) \\
\hline Tacuarembó & Arroyo Laureles & -55.1166 & -33.0833 & Capocasale (1968) \\
\hline Tacuarembó & Chamberlain & -32.6166 & -56.4833 & $\begin{array}{l}\text { NR: } 2 \text { Ô, } 1 \text { immature (FCE - Op 203), 05-xii-1966 } \\
\text { (Carbonell, Moné and San Martín) }\end{array}$ \\
\hline Tacuarembó & Pozo Hondo & -56.2232 & -31.8433 & Capocasale (1968) \\
\hline Tacuarembó & Rincón de Vassoura & -31.3833 & -55.8664 & NR: 2 ㅇ, 19 immatures (MNHN 1402/Z156), 15-xii-1965 \\
\hline
\end{tabular}

NR, new records (with collection data).

precipitation in the period between years 1950 and 2000. Size of the climatic coverages used to build the models (between $-73.525^{\circ} \mathrm{W} /-48.017^{\circ} \mathrm{W}$, and $-17.575^{\circ}$
S/ $-41.692^{\circ} \mathrm{S}$ ) was aimed to embrace not only all distribution points of the selected species (within and outside Uruguay) but also a large adjacent region in southern 
South America, covering Paraguay, Uruguay, southern Brazil, and all Argentina and Chile north of Patagonia. In any case, model maps displayed in Figures 1, 2, 3, and 4 are limited to the Uruguayan portion of our results. To avoid using highly correlated variables, these were selected following criteria applied by Acosta and Guerrero (2011). On the basis of 770 points from the entire study area, we analyzed the correlation of the variable values through a pairwise correlation test, separately for temperature and precipitation variables (Pearson $>0.75$ ). The choice of a variable in a correlated pair (or trio) was primarily evaluated in a preliminary run of the model with all variables, retaining those with the best contribution percentage and/or better rank in the jackknife test. This procedure was performed separately for each species, leading us to select 10 variables for $A$. aculeatus and $P$. thorellii, and 9 for M. paraguayensis (all detailed in Table 2); as previously stated (Acosta and Guerrero 2011), models of $D$. prospicuus were calibrated with 11 variables.

\section{Modeling procedure}

Predictive distributional models were built with MaxEnt (Phillips et al. 2004, 2006), using the version 3.3.3 k of the software (http://www.cs.princeton.edu/ schapire/maxent/). This is a presence/background method that proved better performance than others, like presence-only methods (Peterson et al. 2011). MaxEnt is a maximum entropy algorithm that estimates the probability distribution for a species' occurrence based on the actual occurrence points and the defined environmental constraints (Elith et al. 2006, 2011; Phillips and Dudík 2008; Franklin 2010). Entropy is defined by Shannon (1948) as the choice that is involved in the selection of an event, so maximum entropy refers to maximum choice and closest to uniform (Phillips et al. 2004). The output of the MaxEnt model is a map showing continuous probabilities of presence, so a threshold must be set to define the predicted presence or absence of a species; in our case, we selected 'equal training sensitivity and specificity'. In any case, we preferred to show probability maps (instead of binary ones) to emphasize local differences of the probabilities, more than the boundaries themselves. We set the run to 2,500 maximum iterations, allowing the logistic output format to remove the duplicates from the same grid cell. Maps were displayed by importing models into the free software DIVA-GIS, version 7.1.7 (Hijmans et al. 2005a, b).

\section{Evaluation and relative importance of variables}

MaxEnt evaluates the model's performance using the receiver operating characteristic (ROC) (Hanley and McNeil 1982), frequently used in the evaluation of distribution models based on presence-absence algorithms (Benito de Pando and Peñas de Giles 2007; Peterson et al. 2011). We set the random training data as $75 \%$ of the sample (25\% of the sample as test data). Area under the curve (AUC) is an unbiased measure of discrimination accuracy calculated from the ROC and represents the average sensitivity over all possible specificities (Lobo et al. 2008; Zhonglin et al. 2009). The program automatically calculates the statistical significance of the prediction, using a binomial test of omission that can be used to evaluate the usefulness of the model (Baldwing 2009). An AUC equal to 1.0 represents an ideal diagnostic test because it achieves both $100 \%$ sensitivity and $100 \%$ specificity. If AUC is 0.5 , it indicates that the test has $50 \%$ sensitivity and $50 \%$ specificity rates, suggesting high omission and commission errors, and a model not

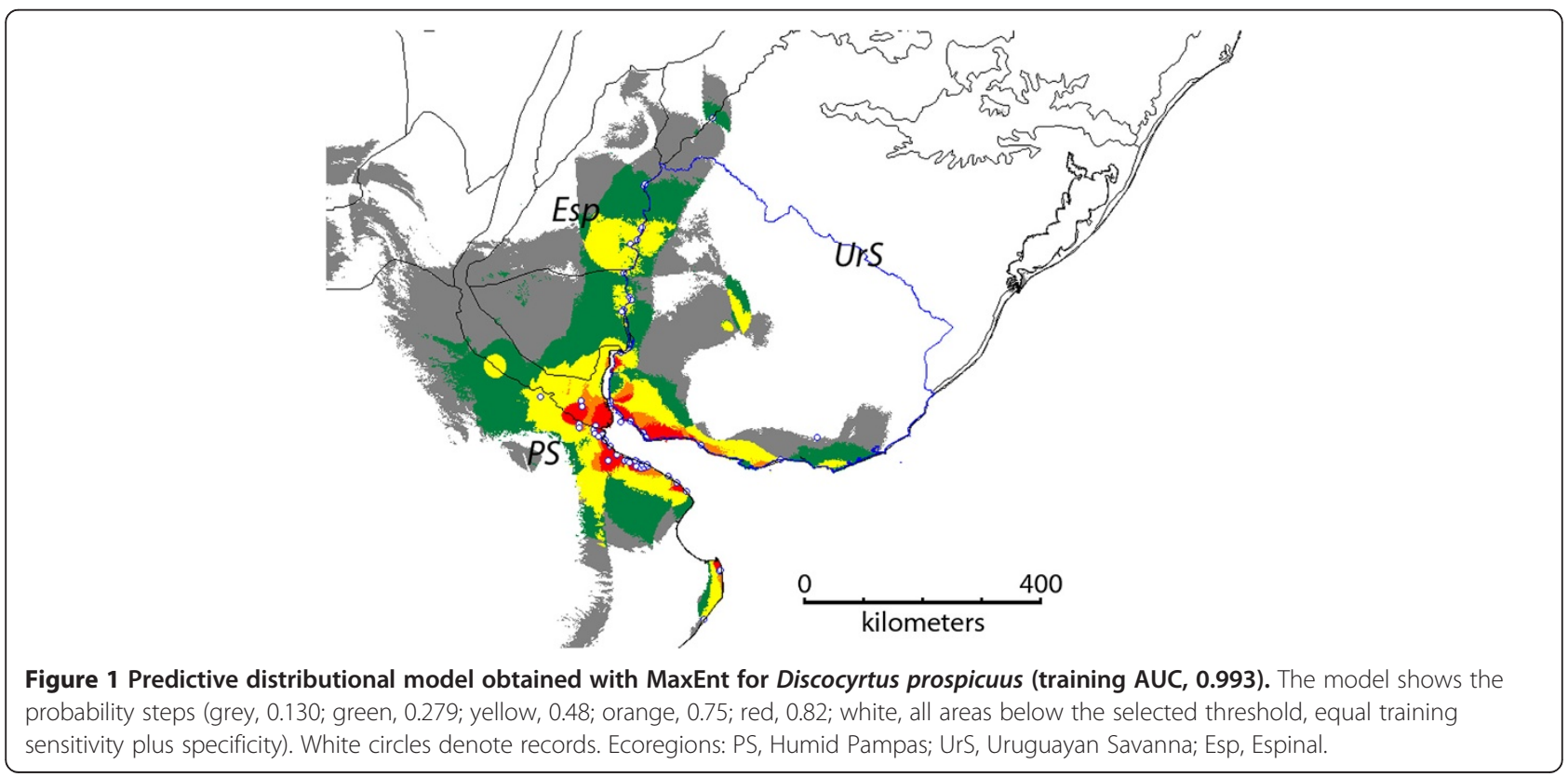




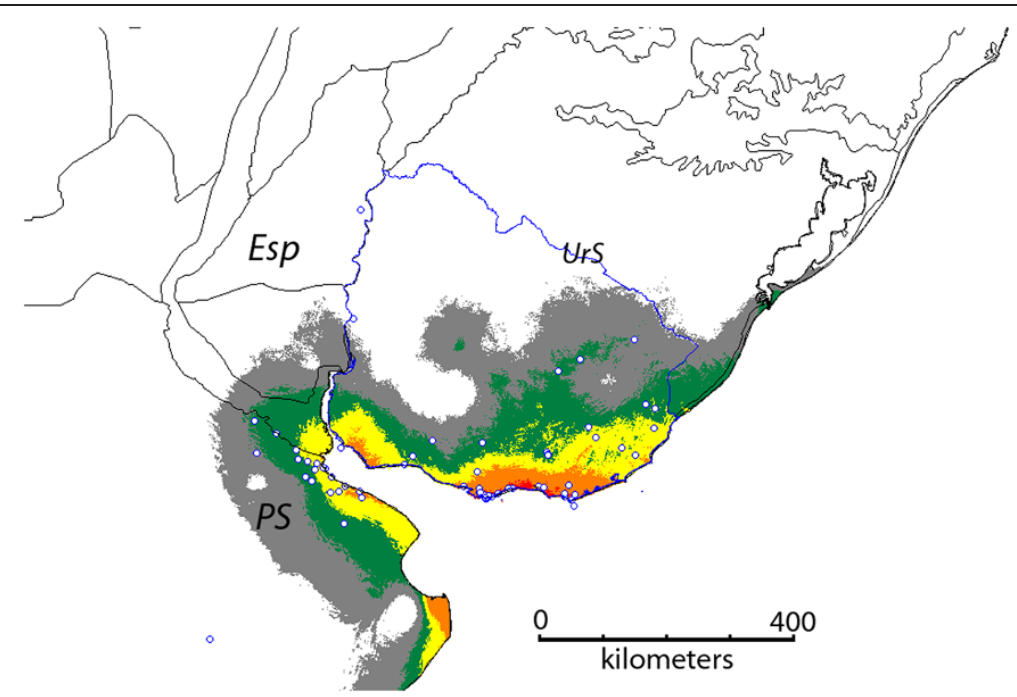

Figure 2 Predictive distributional model obtained with MaxEnt for Pachyloides thorellii (training AUC, 0.982). The model shows the probability steps (grey, 0.186; green, 0.348; yellow, 0.511; orange, 0.674; red, 0.837; white, all areas below the selected threshold, equal training sensitivity plus specificity). White circles denote records. Ecoregions: PS, Humid Pampas; UrS, Uruguayan Savanna; Esp, Espinal.

better than random (Cantor et al. 1999; Saatchi et al. 2008; Peterson et al. 2011; Jiménez-Valverde 2012). To estimate the variables with major incidence in the model, we performed a jackknife analysis to measure variable importance. This method evaluates the importance of each variable and compares it with the other altogether (Peterson et al. 2011).

\section{Results}

\section{Discocyrtus prospicuus}

The distribution of this species in Uruguay is restricted to a narrow corridor along the riparian forest of the coast of Uruguay and Río de la Plata rivers, showing a low probability of occurrence at the center of the country (Figure 1). This species inhabits the islands of Uruguay River, which present subtropical vegetation. Some records were obtained in sites with high synanthropic influence, such as the coast in Villa Argentina in Canelones, and Parque de Vacaciones, UTE in Lavalleja (Figure 1). Two temperature variables presented the highest contribution to the model: isothermality (bc3) and temperature seasonality (bc4) (Table 2). The jackknife analysis indicates that bc3 (isothermality) presented the most information considering all the variables, so that it decreases the

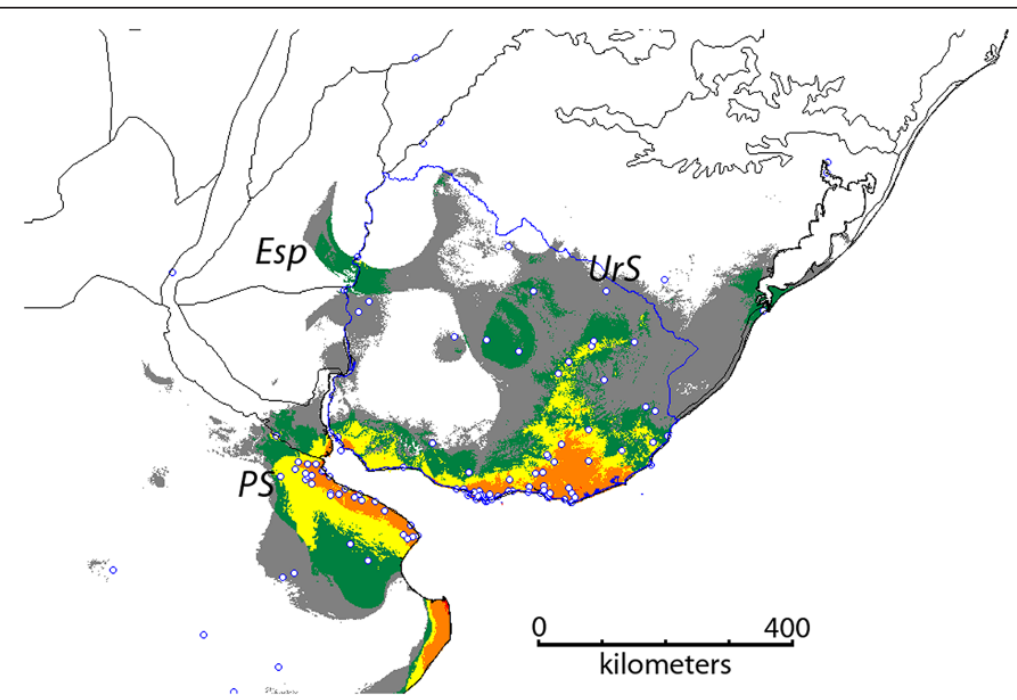

Figure 3 Predictive distributional model obtained with MaxEnt for Acanthopachylus aculeatus (training AUC, 0.980). The model shows the probability steps (grey, 0.177; green, 0.342; yellow, 0.506; orange, 0.671; red, 0.835; white, all areas below the selected threshold, equal training sensitivity plus specificity). White circles denote records. Ecoregions: PS, Humid Pampas; UrS, Uruguayan Savanna; Esp, Espinal. 


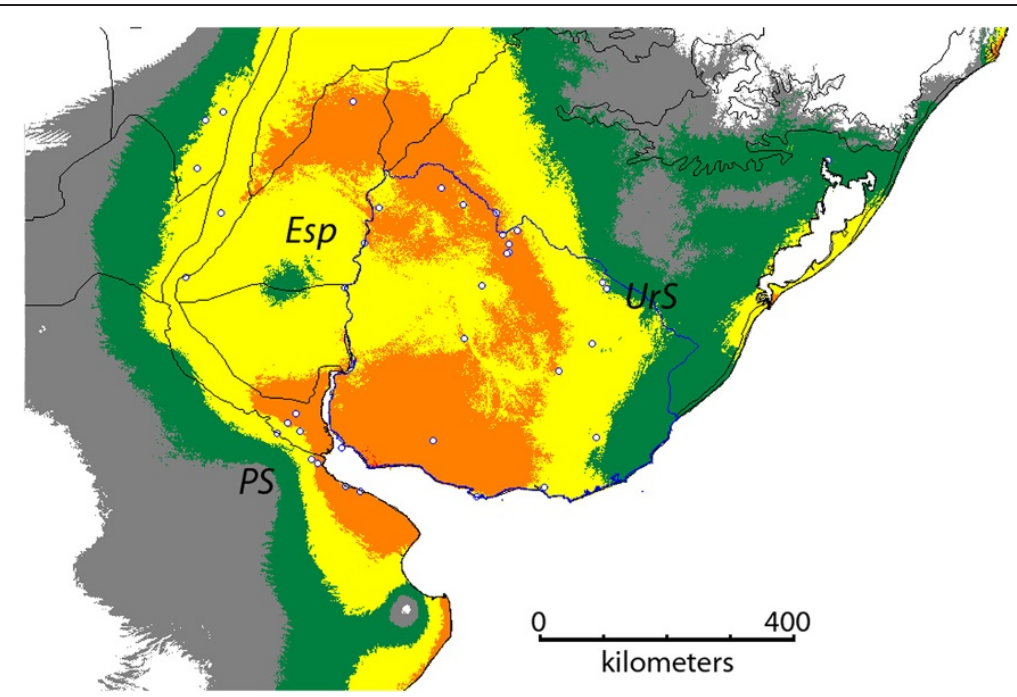

Figure 4 Predictive distributional model obtained with MaxEnt for Metalibitia paraguayensis (training AUC, 0.922). The model shows the probability steps (grey, 0.170; green, 0.336; yellow, 0.502; orange, 0.668; red, 0.834; white, all areas below the selected threshold, equal training sensitivity plus specificity). White circles denote records. Ecoregions: PS, Humid Pampas; UrS, Uruguayan Savanna; Esp, Espinal.

models' gain the most when indicated that omitted (Acosta and Guerrero 2011).

\section{Pachyloides thorellii}

In our analysis, 49 presence records were used for training, 16 for testing, and 10,049 points as background for estimating MaxEnt distribution. The model indicates that this species comprises a Pampasian range along the Rio de la Plata River, with the most suitable area situated at the Uruguayan southeastern coast (Figure 2). This species was recorded in some wetlands, such as Bocas del Sarandí and Potrero Grande in the southeast of the

Table 2 Relative contributions of the environmental variables to the MaxEnt model for the species studied

\begin{tabular}{|c|c|c|c|c|c|c|c|c|c|c|c|c|}
\hline \multirow[t]{2}{*}{ Variable } & \multicolumn{3}{|c|}{$\begin{array}{l}\text { Acanthopachylus } \\
\text { aculeatus }\end{array}$} & \multicolumn{3}{|c|}{$\begin{array}{l}\text { Discocyrtus } \\
\text { prospicuus }\end{array}$} & \multicolumn{3}{|c|}{$\begin{array}{l}\text { Metalibitia } \\
\text { paraguayensis }\end{array}$} & \multicolumn{3}{|c|}{ Pachyloides thorellii } \\
\hline & $\% \mathrm{VC}$ & TGW & $\overline{\text { TGWO }}$ & $\% \mathrm{VC}$ & TGW & $\overline{\text { TGWO }}$ & $\% \mathrm{VC}$ & TGW & $\overline{\text { TGWO }}$ & $\% \mathrm{VC}$ & TGW & TGWO \\
\hline bc1 - annual mean temperature & 6.059 & 2.698 & 1.165 & - & - & - & - & - & - & 14.368 & 2.871 & 1.257 \\
\hline $\begin{array}{l}\text { bc2 - mean diurnal range mean of monthly } \\
\text { (max temp - min temp) }\end{array}$ & 5.472 & 2.728 & 0.966 & 0.232 & 2.983 & 0.522 & - & - & - & 3.066 & 2.934 & 1.080 \\
\hline bc3 - isothermality $(\mathrm{BIO} / \mathrm{BIO} 7)(\times 100)$ & 31.424 & 2.734 & 1.683 & 25.563 & 2.986 & 1.469 & 28.389 & 1.128 & 0.506 & 33.439 & 2.918 & 1.848 \\
\hline bc4 - temperature seasonality (standard deviation $\times 100$ ) & 5.152 & 2.699 & 0.96 & 19.478 & 2.877 & 1.334 & 17.503 & 1.137 & 0.668 & 3.271 & 2.923 & 0.894 \\
\hline bc5 - max temp of warmest month & - & - & - & 0.252 & 2.98 & 0.614 & - & - & - & - & - & - \\
\hline bc6 - min temperature of coldest month & - & - & - & - & - & - & 2.388 & 1.09 & 0.371 & - & - & - \\
\hline bc7 - temperature annual range ( $\mathrm{BlO} 5-\mathrm{BlO} 6)$ & - & - & - & - & - & - & 14.547 & 1.139 & 0.413 & - & - & - \\
\hline bc8 - mean temp of wettest quarter & 2.5 & 2.701 & 0.747 & 5.23 & 2.948 & 0.912 & 3.187 & 1.102 & 0.227 & 0.009 & 2.934 & 0.552 \\
\hline bc9 - mean temp of driest quarter & 0.289 & 2.727 & 0.408 & 0.744 & 2.983 & 1.204 & - & - & - & 0.01 & 2.933 & 0.235 \\
\hline bc11 - mean temp of coldest quarter & - & - & - & 18.791 & 2.937 & 1.457 & - & - & - & - & - & - \\
\hline bc13 - precipitation of wettest month & 8.68 & 2.7 & 0.964 & - & - & - & - & - & - & - & - & - \\
\hline bc14 - precipitation of driest month & 6.784 & 2.727 & 1.349 & - & - & - & 13.412 & 1.15 & 0.401 & 33.549 & 2.922 & 1.383 \\
\hline bc15 - precipitation seasonality (coefficient of variation) & 17.845 & 2.72 & 1.31 & 2.958 & 2.899 & 0.736 & 0.04 & 1.153 & 0.291 & 8.004 & 2.903 & 1.349 \\
\hline bc16 - precipitation of wettest quarter & - & - & - & 9.864 & 2.971 & 0.973 & - & - & - & - & - & - \\
\hline bc17 - precipitation of driest quarter & 15.795 & 2.723 & 1.324 & - & - & - & - & - & - & 3.607 & 2.913 & 1.382 \\
\hline bc18 - precipitation of warmest quarter & - & - & - & 7.723 & 2.976 & 0.976 & 18.948 & 1.119 & 0.512 & 0.677 & 2.920 & 1.237 \\
\hline bc19- precipitation of coldest quarter & - & - & - & 9.163 & 2.295 & 0.967 & 1.588 & 1.141 & 0.256 & - & - & - \\
\hline
\end{tabular}

$\% \mathrm{VC}$, variable percentage contribution; TGW, training gain without; TGWO, training gain with only. Data of Discocyrtus prospicuus are from Acosta and Guerrero (2011). For each species, variables without values were those not selected to build the MaxEnt model. In each column, the highest values are denoted with italics. 
country. Other records were located in forests of hilly systems such as Sierra de Ánimas and Sierra de Minas, where it lives in humid habitats, under stones or litter. Along the coast of Río de la Plata and the Atlantic Ocean, the species was found in patches dominated by hydrophytic vegetation and also in suburban areas, confirming its synanthropic habits (cf. Acosta 1999). The two variables with the highest contribution were precipitation of the driest month (bc14, 33.5\%) and isothermality (bc3, 33.4\%), both with similar values (Table 2 ). The jackknife analysis indicates that bc3 is the variable with highest gain when used in isolation. Furthermore, bc2 (mean diurnal range mean of monthly, 3.07\%) and bc8 (mean temp of wettest quarter, $0.01 \%$ ) have the most information that is not present in the other variables (Table 2).

\section{Acanthopachylus aculeatus}

The analysis was performed on 95 presence records for training, 31 for testing, and 10,095 points to determine the MaxEnt distribution. The distribution model resembles that of $P$. thorellii because both species show a Pampasian distribution along the Rio de la Plata River and the best suitable area is situated at the Uruguayan southeastern coast (Figure 3). Furthermore, A. aculeatus extends the high distribution probabilities to Buenos Aires coast. It is also distributed in other parts of the Uruguayan territory, especially the eastern hills of this country. This species is the most frequently collected in the country, and it was recorded in the same kind of habitats indicated for $P$. thorellii. The two variables with the best contribution were isothermality (bc3, 31.4\%) and precipitation seasonality (bc15, 17.8\%) (Table 2). The jackknife analysis indicates that bc 3 is the variable with highest gain when used in isolation and also it has the most information that is not present in the other variables (Table 2).

\section{Metalibitia paraguayensis}

For the analysis, 47 presence records were used for training, 15 for testing, and 10,047 points for the MaxEnt distribution. In contrast to $A$. aculeatus and $P$. thorellii, $M$. paraguayensis extends the best prediction from southwest to the north of Uruguay, showing a Pampean and Chacoan distribution (Figure 4). The species was recorded in natural environments under trunks or stones in riparian forest and hilly systems of Sierra de las Ánimas, Sierra de Aceguá, Sierra de Mahoma, and Cuchilla Negra. The two variables with the best contribution were isothermality (bc3, 28.4\%) and precipitation of warmest quarter (bc18, 18.9\%) (Table 2). The jackknife analysis indicates that temperature seasonality (bc4, 17.5\%) is the variable with highest gain when used in isolation and precipitation seasonality (bc15, 0.04\%) has the most information that is not present in the other variables (Table 2).

\section{Discussion}

\section{Species distribution models}

At a first glance, predictive maps obtained for three (out of four) representative species of harvestmen seem to support the idea of a uniform distribution pattern. The only species clearly occupying a defined sector in the Uruguayan map is $D$. prospicuus, which has been considered a representative of the 'Mesopotamian' harvestmen-fauna in Argentina (Acosta 2002). As Acosta and Guerrero (2011) showed, range of this species is not typically Mesopotamian since it tends to be limited to the borders of rivers Uruguay and Rio de la Plata, together with some other separate areas. This marginal pattern is clearly reflected in the Uruguayan portion of the species range, following the relationship through the Uruguay River at the west of this country, up to the Rio de la Plata banks (Figure 1). A presumed Paranaense lineage of D. prospicuus is supported by the preference of this species for inhabiting riparian forests and its taxonomic closeness to Discocyrtus bucki (Mello-Leitão 1935) from Misiones, Argentina (Acosta and Guerrero 2011). Like in Argentina, this species was observed in riparian forests in western Uruguay. It was also found in sandy habitats of the coast of the Río de la Plata River and Atlantic Ocean (Toscano-Gadea and Simó 2004). This coast was occupied by psammophile forests in the past. Today, the original habitat was dramatically reduced and fragmented by anthropic activities, and the original vegetation was substituted by exotic plants, only small patches of the original habitat being preserved (Costa et al. 2006). Considering the drastic reduction of native habitat, $D$. prospicuus might be considered as a locally threatened species in southern Uruguay; however, it is not known whether its synanthropic habits may counterbalance such a negative pressure, as suggested for other parts of its range, like the Sierras of Córdoba (Acosta and Guerrero 2011). In this regard, Simó et al. (2000) reported the presence of the spiders Parabatinga brevipes (Keyserling 1891) and Asthenoctenus borellii Simon, 1897 (Ctenidae) in this Uruguayan coastal environment as a result of a positive anthropogenic influence that expanded the range of both species from their natural habitats. Taking all this into account, the predictive distribution model here obtained could be useful for future environmental studies and conservation plans in the southern coast of Uruguay.

As for the remaining species, predictions cover much larger portions of the country. Although presence records of M. paraguayensis in Uruguay concentrate mostly at the north and the center of the country, models predict an extensive range in most of the country and beyond, into Argentina and Brazil. Highest probabilities, indeed, cover only the western half of the country, probably reflecting 
the influence of the neighboring Mesopotamian area sensu stricto (Acosta 2002). In contrast with the other studied species, records of $M$. paraguayensis in Uruguay came only from natural environments, which suggests that it has low tolerance to anthropic influence. In Argentina, however, some records originated in moderately disturbed areas (Acosta 1989).

The two species most frequently represented in arachnological collections are the Pachylinae A. aculeatus and $P$. thorellii; no doubt that this overrepresentation originates in the sampling bias around Montevideo (where both are very common), as already emphasized. Nevertheless, distribution models for these species look closely alike, indicating the highest presence probability in southern Uruguay, along the Rio de la Plata borders. This condition is mirrored by a similar pattern on the Argentinean side (Figure 1). In both cases, high probabilities spread far into the country, but only (or mostly) covering the eastern half. These patterns suggest a rough match with the Oriental dendrofloristic hotspot along the hilly systems of Sierra de las Ánimas and Sierra de Aceguá sensu Grela (2004). Acosta (2002) proposed $A$. aculeatus and $P$. thorellii as representatives of the Pampean area in Argentina. Sharing of these species by Buenos Aires Province and southern Uruguay clearly reflects the biogeographic influence of the Pampean Province in most of the Uruguayan landscape. As already mentioned by Ringuelet (1959) and Acosta (2002), these two species could be benefited from the anthropic activities, expanding their distribution range.

\section{Environmental contribution to the models}

The discrimination capacity of the models was always excellent, taking into account the values obtained of the training AUC for the four species studied (all scoring above 0.9). Isothermality is the temperature variable with the highest contribution to the models of the four species. It is a quantification of the oscillation between monthly diurnal and year temperature, which suggests that these species are sensitive to temperature oscillations. Accordingly, the most suitable conditions are represented in a constrained latitudinal range (from $-29.41^{\circ} \mathrm{S}$ to $-35.49^{\circ} \mathrm{S}$ ), which comprises Uruguay, southern Brazil, and eastern Argentina. A similar distribution pattern was recently reported for the spider Latonigena auricomis Simon, 1893 (Gnaphosidae), for which isothermality was the variable with highest contribution (Jorge et al. 2013). Future studies could be focused on testing if other arachnid species distributions in this latitudinal range could reflect the influence of this climatic variable.

It is worth noting that $P$. thorellii was the only species studied where a precipitation variable (precipitation in the driest month, bc14) had the highest contribution to the model, with a value almost equalling isothermality.

\section{Overall biogeographic pattern}

Sites with a 'biogeographic crossroads' character are considered of high species richness and beta diversity, where evolutionary processes such as speciation and coevolution may be preserved, so they appear to be areas of high conservation priority (Spector 2002). Our results agree with the dendrofloristic distribution proposed by Grela (2004) for Uruguay in the sense that the opiliofauna of Uruguay should be considered as a mosaic showing influence of neighboring biogeographic regions. Geographic similarities between southern Uruguay and Buenos Aires Province, based on geological and zoological studies, indicate the influence of the Pampean Province. Although expectations about the distribution of the opiliofauna in Uruguay were in correlation to the apparent uniformity of the Uruguayan landscape mentioned in previous studies (Capocasale 1968), we consider that at least two roughly different opiliological areas for Uruguay could be proposed, based on climatic variables and reflecting respectively the Pampean and the Mesopotamian/Paranaense influences. The noteworthy prediction of Discocyrtus testudineus (Holmberg 1876) on a narrow fringe along the Uruguayan side of lower Uruguay River (Acosta 2014), even when this species has hitherto no record in the country, may strengthen the mentioned affinity of the west of the country with the Mesopotamian pattern type. Further studies should focus on including other species of Uruguayan harvestmen, additional environmental variables such as vegetation, and new records, especially at the center of the country where a transitional area between the regions is presumed.

\section{Conclusions}

This study recognized at least two different opiliological areas for Uruguay based on climatic variables: a Pampean region that comprises most of the Uruguayan territory and a Mesopotamian/Paranaense region observed in the west and north of the country.

\section{Competing interests}

The authors declare that they have no competing interests.

\section{Authors' contributions}

The paper was originally conceived by MS and LEA. MS, LEA, and JCG analyzed the data. JCG made the figures and tables with MS. LG and IC identified and elaborated a database of the specimens of the Uruguayan arachnological collection. MS, JCG, and LEA finalized the manuscript. All authors read and approved the final manuscript.

\section{Acknowledgements}

We are grateful to Raimundo Real and the reviewers for the useful suggestions and comments that improved the manuscript. LEA is a researcher of the Argentinean Council for Scientific and Technological Research (CONICET) and received support from FONCYT (PICT 2007-1296), CONICET-PIP 2010, and Secretaría de Ciencia y Tecnología, Universidad Nacional de Córdoba. 


\section{Author details}

'Sección Entomología, Facultad de Ciencias, Universidad de la República, Iguá 4225, Montevideo 11400, Uruguay. ' Laboratorio de Entomología, Museo Nacional de Historia Natural Nacional, 25 de Mayo 582, Montevideo 11000, Uruguay. ${ }^{3}$ Programa de Desarrollo de las Ciencias Básicas, PEDECIBA, Universidad de la República, Montevideo, Uruguay. ${ }^{4}$ Laboratorio de Desarrollo Sustentable y Gestión Ambiental del Territorio, Facultad de Ciencias, Universidad de la República, Iguá 4225, Montevideo 11400, Uruguay. ${ }^{5}$ Instituto de Diversidad y Ecología Animal (IDEA), CONICET-Universidad Nacional de Córdoba, Av. Vélez Sarsfield 299, Córdoba 5000, Argentina. ${ }^{6}$ Cátedra de Diversidad Animal I, Facultad de Ciencias Exactas, Físicas y Naturales, Universidad Nacional de Córdoba, Av. Vélez Sarsfield 299, Córdoba 5000, Argentina.

\section{Received: 14 October 2013 Accepted: 22 July 2014} Published: 7 August 2014

\section{References}

Acosta LE (1989) La fauna de escorpiones y opiliones (Arachnida) de la provincia de Córdoba. Ph. D. Thesis. Facultad de Ciencias Exactas, Físicas y Naturales, Universidad Nacional de Córdoba, p 333

Acosta LE (1992) Las especies argentinas de Parabalta descriptas por Carl F. Roewer (Opiliones, Gonyleptidae, Pachylinae). Revta Soc Ent Argent 50(1-4):167-178

Acosta LE (1993) Escorpiones y opiliones de la provincia de Córdoba (Argentina): diversidad y zoogeografía. Bull Soc Neuchât Sei Nat 116(1):11-17

Acosta LE (1999) New synonyms in the genera Discocyrtus and Pachyloides (Opiliones, Gonyleptidae, Pachylinae). J Arachnol 27(2):465-469

Acosta LE (2002) Patrones zoogeográficos de los opiliones argentinos (Arachnida: Opiliones). Rev Iber Aracnol 6:69-84

Acosta LE (2008) Distribution of Geraeocormobius sylvarum (Opiliones, Gonyleptidae): range modeling based on bioclimatic variables. J Arachnol 36(3):574-582

Acosta LE (2014) Bioclimatic profile and potential distribution of the Mesopotamian harvestman Discocyrtus testudineus (Holmberg, 1876) (Opiliones, Gonyleptidae). Zootaxa 3821(3):301-320

Acosta LE, Guerrero EL (2011) Geographical distribution of Discocyrtus prospicuus (Arachnida: Opiliones: Gonyleptidae): is there a pattern? Zootaxa 3043:1-24

Acosta LE, Maury EA (1998a) Scorpiones. In: Coscarón S, Morrone JJ (ed) Biodiversidad de Artrópodos argentinos. Una perspectiva biotaxonómica. Ediciones Sur, La Plata

Acosta LE, Maury EA (1998b) Opiliones. In: Morrone JJ, Coscarón S (ed) Biodiversidad de Artrópodos argentinos. Una perspectiva biotaxonómica. Ediciones Sur, La Plata

Acosta LE, Candido DM, Buckup EH, Brescovit AD (2008) Description of Zabius gaucho (Scorpiones, Buthidae), a new species from southern Brazil, with an update of the generic diagnosis. J Arachnol 36(3):491-501

Baldwing RA (2009) Use of maximum entropy modeling in wildlife research. Entropy 11:854-866

Benito de Pando B, Peñas de Giles J (2007) Aplicación de modelos de distribución de especies a la conservación de la biodiversidad en el sureste de la Península Ibérica. GeoFocus Rev Int Cien Tecnol Inf Geog 7:100-119

Cabrera A, Willink A (1973) Biogeografía de América Latina. Serie Biología. Monografía OEA 13:1-122

Cantor SB, Sun CC, Tortolero-Luna G, Richards-Kortum R, Follen M (1999) A comparison of $\mathrm{C} / \mathrm{B}$ ratios from studies using receiver operating characteristic curve analysis. J Clin Epidemiol 52:885-892

Capocasale R (1968) Nuevos aportes para el conocimiento de la distribución geográfica de Opiliones de Uruquay. Neotropica 14(44):65-71

Capocasale R (2003) Diversidad de la biota uruguaya: Opiliones. An Mus Nac Hist Nat y Antrop 10(2):1-8

Capocasale R, Gudynas E (1993) La fauna de opiliones (Arachnida) del criptozoos de Sierra de las Ánimas (Uruguay). Aracnología 19(20):1-15

Carlini AA, Zurita AE, Gasparini GM, Noriega JI (2004) Los mamíferos del Pleistoceno de la Mesopotamia argentina y su relación tanto con aquellos del Centro-Norte de la Argentina, Paraguay, sur de Bolivia, como con los del sur de Brasil y oeste de Uruguay: Paleobiogeografía y Paleoambientes. INSUGEO (Misceláneas) 12:5-12

Costa F, Simó M, Aisenberg A (2006) Composición y ecología de la fauna epígea de Marindia (Canelones, Uruguay) con especial énfasis en las arañas: un estudio de dos años con trampas de intercepción. In: Menafra R, Rodríguez-
Gallego L, Scarabino F, Conde D (ed) Bases para la conservación y el manejo de la costa uruguaya. Vida Silvestre, Montevideo

Crisci J, Freire S, Sancho G, Katinas L (2001) Historical biogeography of the Asteraceae from Tandilia and Ventania mountain ranges (Buenos Aires, Argentina). Caldasia 23(1):21-41

Elith J, Graham CH, Anderson RP, Dudik M, Ferrier S, Guisan A, Hijmans RJ, Huettmann F, Leathwick JR, Lehmann A, Li J, Lohmann LG, Lioselle BA, Manion G, Moritz C, Nakamura M, Nakazawa Y, Overton J, Peterson AT, Phillips SJ, Richardson K, Scachetti-Pereira R, Schapire RE, Soberón J, Williams S, Wisz MS, Zimmermann NE (2006) Novel methods improve prediction of species' distributions from occurrence data. Ecography 29:129-151

Elith J, Phillips SJ, Hastie T, Dudı'k M, Chee YE, Yates CJ (2011) A statistical explanation of MaxEnt for ecologists. Divers Distrib 17:43-57

Evia G, Gudynas E (2000) Ecología del Paisaje en Uruguay. Aportes para la conservación de la Diversidad Biológica. MVOTMA, AECI and Junta de Andalucía, Montevideo

Ferretti N, González A, Pérez-Miles F (2012) Historical biogeography of mygalomorph spiders from the peripampasic orogenic arc based on track analysis and PAE as a panbiogeographical tool. Syst Biodivers 10(2):179-193

Franklin J (2010) Mapping species distributions. Cambridge University Press, Cambridge. Spatial inference and prediction

Grela I (2004) Geografía florística de las especies arbóreas de Uruguay: propuesta para la delimitación de dendrofloras. Master Dissertation. PEDECIBA Biología, Universidad de la República

Guerrero EL (2011) Riqueza específica en una taxocenosis de Opiliones (Arachnida) en la localidad de Lima, provincia de Buenos Aires, Argentina. Hist Nat 1:35-45

Hanley JA, McNeil BJ (1982) The meaning and use of the area under a receiver operating characteristic (ROC) curve. Radiology 143:29-36

Hijmans RJ, Guarino L, Jarvis A, O'Brien R, Mathur P (2005a) DIVA-GIS ver. 5.4 Available on line at: http://www.diva-gis.org. Accessed 3 April 2013

Hijmans RJ, Cameron S, Parra JL, Jones PG, Jarvis A (2005b) Very high resolution interpolated climate surfaces for global land areas. Int J Climatol 25:1965-1978

Holmberg EL (1876) Arácnidos argentinos. An Agric Rep Arg 4:1-30

Holmberg EL (1878) Notas aracnológicas. Sobre los solpúgidos argentinos. El Nat Arg 1(3):69-74

Jiménez-Valverde A (2012) Insights into the area under the receiver operating characteristic curve (AUC) as a discrimination measure in species distribution modelling. Global Ecol Biogeogr 21:498-507

Jorge C, Carrión NL, Grismado C, Simó M (2013) On the taxonomy of Latonigena auricomis (Araneae, Gnaphosidae), with notes of geographical distribution and natural history. Iheringia (Zool) 103:66-71

Keyserling E (1891) Die Spinnen Amerikas. Brazilianische Spinnen. Nürnberg 3

Kirby W (1818) A century of Insects, including several new genera described from his cabinet. Trans Linn Soc London 12:375-453

Kury AB (2003) Annotated catalogue of the Laniatores of the New World (Arachnida, Opiliones). Rev Iber Aracnol Special monographic, vol 1, pp 1-337

Laborda A, Montes de Oca L, Useta G, Pérez-Miles F, Simó M (2012) Araneae, Deinopidae, Deinopis amica Schiapelli and Gerschman, 1957: first record for Uruguay and distribution map. Check-List 8(6):1301-1302

Lobo JM, Jiménez-Valverde A, Real R (2008) AUC: a misleading measure of the performance of predictive distribution models. Global Ecol Biogeogr 17:145-151

Mattoni Cl, Acosta LE (1997) Scorpions of the insular Sierras in the Llanos District (Province of La Rioja, Argentina) and their zoogeographical links. Biogeographica 73:67-80

Mello-Leitão C de (1935) Alguns novos opiliões do Estado de S. Paulo e do Distrito Federal. Arch Mus Nac Río de Janeiro 36:9-37

Morrone JJ (2002) Biogeografía de América Latina y el Caribe. Manuales y Tesis Sociedad Entomológica. Aragonesa, Zaragoza

Olson DM, Dinerstein E, Wikramanayake ED, Burgess ND, Powell GVN, Underwood EC, D'Amico JA, Itoua I, Strand HE, Morrison JC, Loucks CJ, Allnutt TF, Ricketts TH, Kura Y, Lamoreux JF, Wettengel WW, Hedao P, Kassem KR (2001) Terrestrial ecoregions of the world: a new map of life on Earth. BioScience 51:933-938

Peterson AT, Soberón J, Pearson RG, Anderson RP, Martínez-Meyer E, Nakamura M, Araújo MB (2011) Ecological niches and geographic distributions. Princeton University Press, Oxford

Phillips SJ, Dudík M (2008) Modeling of species distributions with Maxent: new extensions and a comprehensive evaluation. Ecography 31:161-175

Phillips SJ, Dudík M, Schapire RE (2004) A maximum entropy approach to species distribution modeling. In: Proceedings of the Twenty-First International Conference on Machine Learning, pp 655-662 
Phillips SJ, Anderson RP, Schapire RE (2006) Maximum entropy modeling of species geographic distributions. Ecol Model 190:231-259

Pinto da Rocha R, Bernardino da Silva M, Bragagnolo C (2005) Faunistic similarity and historic biogeography of the harvestmen of southern and southeastern Atlantic rain forest of Brazil. J Arachnol 33:290-299

Pinto da Rocha R, Machado G, Giribet G (ed) (2007) Harvestmen - the biology of Opiliones. Harvard University Press, Cambridge and London

Ringuelet RA (1955) Noticias sobre opiliones del Uruguay. Notas Mus La Plata 18. Zool 163:279-297

Ringuelet RA (1959) Los arácnidos argentinos del Orden Opiliones. Rev Mus Argent C Nat, C Zool 5:127-439

Ringuelet RA (1963) Opiliofauna uruguaya. Revta Soc Ent Argent 24:35-51

Saatchi S, Buermann W, ter Steege H, Mori S, Smith T (2008) Modeling distribution of Amazonian tree species and diversity using remote sensing measurements. Remote Sens Environ 112:2000-2017

Shannon CE (1948) A mathematical theory of communication. AT \& T Tech J 27(3):379-423

Simó M, Vázquez V, Useta G (2000) Estudio comparativo de la fenología y el hábitat de Ctenus taeniatus Keyserling, 1891 y Asthenoctenus borellii Simon, 1897 en el Uruguay (Araneae, Ctenidae). Bol Soc Zool Uruguay 12:32-40

Simon E (1893) Études arachnologiques. 25e Mémoire. XL. Descriptions d'espèces et de genres nouveaux de l'ordre des Araneae. Ann Soc entomol Fr 62(2):299-330

Simon E (1897) Liste de arachides recueillis aux îles du Cap Vert, dans la République Argentine et le Paraguay et descriptions d'espèces nouvelles. In Viaggio del Dott. A. Borelli nella République Argentina e nel Paraguay. Boll Mus Zool Anat Comp Torino 12(270):1-8

Soares HEM, Soares BAM (1986) Opera opiliologica varia. XXVI (Opiliones, Gonyleptidae). Revta Bras Ent 30(1):87-100

Sørensen W (1884) Opiliones Laniatores (Gonyleptides W. S. olim). Mus Hauniensis Naturh Tidskr 3(14):555-646

Spector S (2002) Biogeographic crossroads as priority areas for biodiversity conservation. Conserv Biol 16(6):1480-1487

Toscano-Gadea C, Simó M (2004) La fauna de opiliones de un área costera del Río de la Plata. Rev Iber Aracnol 10:157-162

Van Der Wal J, Shoo LP, Graham C, Williams SE (2009) Selecting pseudo-absence data for presence-only distribution modeling: how far should you stray from what you know? Ecol Model 220:589-594

Zhonglin X, Chuanyan Z, Zhaodong F (2009) A study of the impact of climate change on the potential distribution of Qinghai spruce (Picea crassifolia) in Qilian Mountains. Acta Ecol Sin 29:278-285

doi:10.1186/s40555-014-0050-2

Cite this article as: Simó et al: A predictive modeling approach to test distributional uniformity of Uruguayan harvestmen (Arachnida: Opiliones). Zoological Studies 2014 53:50.

\section{Submit your manuscript to a SpringerOpen ${ }^{\circ}$ journal and benefit from:}

- Convenient online submission

- Rigorous peer review

- Immediate publication on acceptance

- Open access: articles freely available online

- High visibility within the field

- Retaining the copyright to your article

Submit your next manuscript at $\gg$ springeropen.com 